\title{
IN VITRO ACTIVITY OF ANTIFUNGAL AND ANTISEPTIC AGENTS AGAINST DERMATOPHYTE ISOLATES FROM PATIENTS WITH TINEA PEDIS
}

\author{
Maria Magali Stelato Rocha Soares ${ }^{1 *}$; Arlete Emily Cury ${ }^{2}$ \\ 'Instituto de Ciências Biológicas e Químicas, Faculdade de Ciências Farmacêuticas, \\ PUC de Campinas, Campinas, SP, Brasil. ${ }^{2}$ Faculdade de Ciências Farmacêuticas, Universidade de São Paulo, \\ São Paulo, SP, Brasil.
}

Submitted: February 02, 2001; Approved: May 28, 2001

\begin{abstract}
The in vitro activity of antifungal and antiseptic agents were evaluated against dermatophytes isolated from patients with tinea pedis. The antifungals studied were: ciclopirox olamine, cetoconazole, tolciclate and terbinafine, and the antiseptics were: povidine iodine (PVPI), propolis, Fungol ${ }^{\circledR}$, Andriodermol ${ }^{\circledR}$, and boric acid. The minimum inhibitory concentration (MIC) or the minimal dilution concentration (MDC) was determined by an agar dilution method using modified yeast nitrogen agar base, and the minimum fungicidal concentration (MFC) or minimum fungicidal dilution (MFD) was determined with subcultures on Sabouraud dextrose agar. All drugs studied were active against the dermatophytes at lower concentrations than those used in products and/or pharmaceutical preparations for topical use. Some antifungal agents, mainly terbinafine and tolciclate, presented higher efficacy than the other drugs, with lower MICs and MFCs values. It was concluded that the use of these antiseptic drugs represent an excellent alternative for the topical treatment of tinea pedis. For the treatment of severe cases these are the antifungal agents of choice.
\end{abstract}

Key words: dermatophytes, antifungal agents, antiseptic agents, susceptibility testing, tinea pedis

\section{INTRODUCTION}

Tinea pedis is one of the most frequent mycoses; it occurs in several classes of patients, but especially in immunosupressed individuals (21).

Topical or systemic treatments have been empirically administered, when, in general, specific antifungal agents are employed $(3,13,18)$. Although such drugs are widely used, some of them have been reported as ineffective and even toxic to the host $(3,4,9,10,13,18)$. These factors have lead to the development and marketing of new drugs, but most of them have the same pharmacological active groups and the same mechanisms of action as those previously commercially available $(9,10,13)$. However, some fungi are significantly different regarding susceptibility to such drugs $(5,8,12,20,23,24)$.
Therefore, despite the need of further studies focusing on the solution of these medical problems, there has been increasing interest in the usage of chemical substances with non-specific activity in the treatment of mycoses, such as antiseptic drugs $(2,6,11,14,16)$.

The aim of this study was to evaluate the in vitro activity of commercially available antifungal and antiseptic agents against dermtophytes isolated from patients with tinea pedis.

\section{MATERIALS AND METHODS}

\section{Patients}

In this study, 313 patients suspected of being infected with tinea pedis were selected: 177 patients were from the dermatology clinic of the Hospital e Maternidade Celso Pierro (HMCP - PUC

\footnotetext{
* Corresponding author. Mailing address: Instituto de Ciências Biológicas e Químicas, Laboratório de Microbiologia, PUC de Campinas, Av. John Boyd Dunlop, s/n, Jd. Ipaussurama, Caixa Postal 1111. 13059-900, Campinas, SP, Brasil. Tel.: (+5519) 729-8307. Fax: (+5519) 729-8517. E-mails microimu.acad.pucamp.com.br. or magali_soares@uol.com.br
} 
de Campinas) and 136 cadets and soldiers were from the military academy clinic (Escola Prepatória de Cadetes do Exército EsPECx).

\section{Mycological tests}

Collection and direct examination of the clinical samples, as well as isolation and fungal identification were performed according to classic techniques $(13,17)$.

\section{Susceptibility testing}

\section{Microorganisms and Inoculum}

Sixty six dermatophytes were isolated from the patients under study, including 25 strains of Trichophyton rubrum, 36 strains of Trichophyton mentagrophytes, and 5 strains of Epidermophyton floccosum. These strains were maintained on Saboraud dextrose agar (SDA) and potato dextrose agar (PDA) at $27-30^{\circ} \mathrm{C}$. They were subcultured at 3 months intervales, but observed on a weekly bases. Just before use, the samples were transferred to SDA and maintained for 7 days at $27^{\circ} \mathrm{C}-30^{\circ} \mathrm{C}$ $(17,19,20)$.

The strains Candida pseudotropicalis "Carshanton" and $C$. krusei 6258 , both sensitive to cetoconazole (MIC range: 0.25 to 4 $\mu \mathrm{m} / \mathrm{ml}$ ), were used as controls. They had been obtained from the Centro de Referência da Faculdade de Medicina, USP, SP. These yeasts were maintained on SDA under the same conditions as the dermatophytes. During this study, they were kept on SDA for 24 hours at $27^{\circ} \mathrm{C}-30^{\circ} \mathrm{C}(17,19,20)$.

The inoculum was prepared according to previous studies (20), and attained aproximately $10^{6} \mathrm{cels} / \mathrm{ml}$.

\section{Antifungal and antiseptic agents}

Commercially available products were utilized. The antifungal drugs were cetoconazole and ciclopirox olamine (Galena Química Farmacêutica Ltda), tolciclate (Carlo Erba S.A.) and terbinafine cloridrate (Sandoz S.A.). The antiseptics were Andriodermol ${ }^{\circledR}$ (Searle do Brasil Ltda), Fungol ${ }^{\circledR}$ (Laboratório Silva Araujo Roussel), Propolis (Uniflora Apicultores Associados Ltda), boric acid (Indafarma Indústria e Comércio de Produtos Químicos Ltda) and povidine iodine (PVPI - Galena Química Farmacêutica Ltda).

The antifungal agents were kept at $4^{\circ} \mathrm{C}$ under vacuum, and the antiseptic agents were maintained at room temperature. All the drugs were kept away from light and moisture.

The stock solutions of cetoconazole, terbinafine and tolciclate were prepared in dimethilsulphoxide (DMSO); the stock solutions of ciclopirox olamine, PVPI and Andriodermol ${ }^{\circledR}$ were prepared in absolute alcohol and the boric acid stock solution was prepared in water $(17,19,20)$. Organic solutions were left at room temperature for 30 minutes in order to sterilize them. The aqueous solutions were sterilized by filtration $(0.22 \mu \mathrm{m}$ filter $)$ $(17,19,20)$. It was not necessary to prepare stock solutions of Fungol® and Propolis.

\section{Performance and reading}

The susceptibility tests were performed as previously described (20) with modifications. The tests were performed in duplicates and the final results were presented as the arithmetic average of the values obtained.

Some fungi cultures were lost during the study, therefore not all drugs were studied against all dermatophyte isolates.

Determination of minimum inhibitory concentration (MIC) or minimum inhibitory dilution (MID)

From each antifungal agent stock solution, decimal dilutions were prepared in modified yeast nitrogen base broth (YNBP). For each dilution, $2 \mathrm{ml}$ were added to $18 \mathrm{ml}$ of YNBP before plating. Under such conditions, the antifungal agent's concentrations ranged from 128 to $0.25 \mu \mathrm{g} / \mathrm{ml}$ for PVPI, cetoconazole and ciclopirox olamine; from 16 to $0.031 \mu \mathrm{g} / \mathrm{ml}$ for tolciclate; from 4.0 to $0.007 \mu \mathrm{g} /$ $\mathrm{ml}$ for terbinafine; from 512 to $1.0 \mu \mathrm{g} / \mathrm{ml}$ for boric acid and from 2000 to $3.9 \mu \mathrm{g} / \mathrm{ml}$ for própolis. Since Andriodermol $\AA$ and Fungol $\AA$ contain several active ingredients, they were studied at dilutions ranging from $1: 150$ to $1: 76800$ and from $1: 100$ to $1: 25600$, respectively.

In these tests, two additional plates were prepared as controls. The first plate contained YNBP without any drug (B1) while the second plate contained YNBP with the proper diluent concentration for each specific drug studied (B2).

One $\mu l$ of each dermatophyte and the control yeast suspension was placed on each plate. The plates were incubated at $27^{\circ} \mathrm{C}-30^{\circ} \mathrm{C}$ until visible growth of each fungus in the $\mathrm{B} 1$ control (around 5 to 7 days).

The MIC or MID was defined as the lowest concentration or highest dilution of the antifungal agent which resulted in plates without visible colonies.

\section{Determination of minimum fungicidal concentration (MFC) or minimum fungicidal dilution (MFD)}

Each inoculum which resulted in no growth in the previous test and the growth on the control plates (B1 and B2) were subcultured on SDA. The plates were incubated at $27^{\circ} \mathrm{C}-30^{\circ} \mathrm{C}$ until growth of subculture on the control plates was visible.

The MFC or MFD was defined as the lowest concentration or highest dilution of drug resulted in plates without visible colonies.

\section{RESULTS}

\section{Ciclopirox olamine}

The activity of this antifungal agent, in terms of MIC, ranged from $8 \mu \mathrm{g} / \mathrm{ml}$ to $32 \mu \mathrm{g} / \mathrm{ml}$. However, most strains of T. rubrum and T. mentagrophytes and 2 isolates of E. floccosum were inhibited at the concentration of $16 \mu \mathrm{g} / \mathrm{ml}$. The MFC ranged from $16 \mu \mathrm{g} / \mathrm{ml}$ to $>128 \mu \mathrm{g} / \mathrm{ml}$. Concentrations up to $64 \mu \mathrm{g} / \mathrm{ml}$ were not lethal for 4 (12.9\%) strains of T. mentagrophytes (Table 1). 


\section{Terbinafine}

The MICs of terbinafine for the strains were $0.007 \mu \mathrm{g} / \mathrm{ml}$ or $0.015 \mu \mathrm{g} / \mathrm{ml}$. Most strains of T. rubrum $(16 ; 72.7 \%), T$. mentagrophytes $(24 ; 72.7 \%)$ and E. floccosum $(2 ; 50 \%)$ were inhibited at concentration of $0.007 \mu \mathrm{g} / \mathrm{ml}$. The MFC ranged from $0.03 \mu \mathrm{g} / \mathrm{ml}$ to $>4 \mu \mathrm{g} / \mathrm{ml}$. This antifungal agent was lethal to two strains of E. floccosum at the concentration of $0.03 \mu \mathrm{g} / \mathrm{ml}$, and at $0.5 \mu \mathrm{g} / \mathrm{ml}$ it was lethal to the other two strains. The fungicidal concentration for $13(59.1 \%)$ strains of T. rubrum was up to 0.25 $\mu \mathrm{g} / \mathrm{ml}$, and for $20(60.6 \%)$ strains of T. mentagrophytes it was up to $0.5 \mu \mathrm{g} / \mathrm{ml}$. Only 2 and 6 strains of T.rubrum and T. mentagrophytes, respectively, were not killed by concentrations up to $4 \mu \mathrm{g} / \mathrm{ml}$ (Table 1 ).

\section{Cetoconazole}

The activity of cetoconazole, in terms of MIC, ranged from 1 $\mu \mathrm{g} / \mathrm{ml}$ to $32 \mu \mathrm{g} / \mathrm{ml}$. Yet, at concentrations up to $4 \mu \mathrm{g} / \mathrm{ml}$ it inhibited most strains of T. rubrum $(15 ; 68.2 \%)$ and T mentagrophytes $(23$; $67.6 \%$ ). Among the five strains of E. floccosum, four were inhibited at concentrations up to $2 \mu \mathrm{g} / \mathrm{ml}$. The MFC of this antifungal agent ranged from $4 \mu \mathrm{g} / \mathrm{ml}$ to $>128 \mu \mathrm{g} / \mathrm{ml}$. It was observed that the lethal concentrations for most isolates of $T$. rubrum $(12 ; 54.5 \%)$ and T. mentagrophytes $(20 ; 58.8 \%)$ were up to $16 \mu \mathrm{g} / \mathrm{ml}$ and $32 \mu \mathrm{g} / \mathrm{ml}$, respectively, while for $12(35,3 \%)$ isolates of T. mentagrophytes and two of E. floccosum it was 128 $\mu \mathrm{g} / \mathrm{ml}$ (Table 1).

\section{Tolciclate}

For this antifungal agent, the MICs ranged from $0.03 \mu \mathrm{g} / \mathrm{ml}$ to $0.5 \mu \mathrm{g} / \mathrm{ml}$. Most isolates of T. rubrum (18; 78.3\%), T. mentagrophytes
$(19 ; 57.6 \%)$ as well as two strains of $E$. floccosum were inhibited at concentrations of $0.06 \mu \mathrm{g} / \mathrm{ml}$. The susceptibility, in terms of MFC, ranged from $0.5 \mu \mathrm{g} / \mathrm{ml}$ to $>16 \mu \mathrm{g} / \mathrm{ml}$. The lethal concentration for most strains of the three species studied was up to $4 \mu \mathrm{g} / \mathrm{ml}$. Two strains of T. rubrum were regarded as exceptions; for one of them, the MFC was $8 \mu \mathrm{g} / \mathrm{ml}$, and for the other, it was > $16 \mu \mathrm{g} / \mathrm{ml}$ (Table 1).

\section{PVPI}

The MICs for PVPI ranged from $4 \mu \mathrm{g} / \mathrm{ml}$ to $>128 \mu \mathrm{g} / \mathrm{ml}$. However, only one strain each of T.rubrum and T. mentagophytes was inhibited at concentrations $>128 \mu \mathrm{g} / \mathrm{ml}$. The MFCs ranged from 8 $\mu \mathrm{g} / \mathrm{ml}$ a $>128 \mu \mathrm{g} / \mathrm{ml}$. Concentrations up to $128 \mu \mathrm{g} / \mathrm{ml}$ were not lethal to 3 strains of T. rubrum and one of T. mentagrophytes. For two strains of E. floccosum the lethal concentration was $32 \mu \mathrm{g} / \mathrm{ml}$ and for two other, it was $128 \mu \mathrm{g} / \mathrm{ml}$ (Table 2).

\section{Boric acid}

Boric acid's MICs ranged from $64 \mu \mathrm{g} / \mathrm{ml}$ to $512 \mu \mathrm{g} / \mathrm{ml}$. However, most isolates of T. rubrum $(14 ; 63.6 \%)$ and of $T$. mentagrophytes (32; $91.4 \%)$ were inhibited respectively up to $256 \mu \mathrm{g} / \mathrm{ml}$ and 512 $\mu \mathrm{g} / \mathrm{ml}$. One of the $E$. floccosum strains was inhibited at $128 \mu \mathrm{g} / \mathrm{ml}$, while two others were inhibited at $512 \mu \mathrm{g} / \mathrm{ml}$, but 2 of the strains was not susceptible to this antifungal agent at the concetrations studied. The MFCs ranged from $512 \mu \mathrm{g} / \mathrm{ml}$ to $>512 \mu \mathrm{g} / \mathrm{ml}$ against the three species of dermatophytes studied. (Table 2).

\section{Propolis}

The MICs of this agent ranged from $7.81 \mu \mathrm{g} / \mathrm{ml}$ to $>2000$ $\mu \mathrm{g} / \mathrm{ml}$. However, most strains of T. rubrum $(12 ; 54.5 \%)$ were

Table 1. In vitro susceptibility of dermatophytes to four antifungal agents.

\begin{tabular}{cccccc}
\hline Dermatophytes & S.T. $^{*}$ & ciclopirox olamine & terbinafine & cetoconazole & tolciclate \\
\hline T. rubrum & MIC & $8-32$ & $0.007-0.015$ & $1-32$ & $0.003-0.125$ \\
& MFC & $16-64$ & $0.03->4$ & $4-128$ & $1->16$ \\
T.mentagrophytes & MIC & $16-32$ & $0.007-0.015$ & $1-32$ & $0.003-0.5$ \\
& MFC & $16->128$ & $0.03->4$ & $8->128$ & $0.5-4$ \\
E. floccosum & MIC & -32 & $0.007-0.015$ & $1-8$ & $0.003-0.25$ \\
& MFC & $16-32$ & $0.03->0.5$ & $16-128$ & $1-4$ \\
\hline
\end{tabular}

*S.T. = Susceptibilty testing range of activity of antifungal agents at different concentration $(\mu \mathrm{g} / \mathrm{ml}) ; \mathrm{MIC}=$ minimum inhibitory concentration; $\mathrm{MFC}=$ minimum fungicidal concentration .

Table 2. In vitro susceptibility of dermatophytes to three antiseptic agents.

\begin{tabular}{ccccc}
\hline Dermatophytes & S.T. & PV PI & boric acid & propolis \\
\hline T. rubrum & MIC & $1->128$ & $64->512$ & $7.81-2000$ \\
& MFC & $16->128$ & $512->512$ & $1000->2000$ \\
T. mentagrophytes & MIC & $8->128$ & $64->512$ & $62.5->500$ \\
& MFC & $8->128$ & $512->512$ & $1000->2000$ \\
E. floccosum & MIC & $16-128$ & $128->512$ & $125-250$ \\
& MFC & $32-128$ & $512->512$ & $1000->2000$ \\
\hline
\end{tabular}

S.T. $=$ Susceptibilty testing range of activity of antifungal agents at different concentration $(\mu \mathrm{g} / \mathrm{ml}) ; \mathrm{MIC}=$ minimum inhibitory concentration; $\mathrm{MFC}=$ minimum fungicidal concentration . 
Table 3. In vitro susceptibility of dermatophytes to two antiseptic agents.

\begin{tabular}{cccc}
\hline Dermatophytes & S.T. & Fungol $^{\mathrm{R}}$ & Andriodermol $^{\mathrm{R}}$ \\
\hline T. rubrum & MID & $1 / 3200->1 / 100$ & $1 / 38400->1 / 600$ \\
& MFD & $1 / 800->1 / 100$ & $1 / 2400->1 / 150$ \\
T. mentagrophytes & MID & $1 / 800->1 / 100$ & $1 / 9600->1 / 600$ \\
& MFD & $1 / 400->1 / 100$ & $1 / 2400->1 / 150$ \\
E. floccosum & MID & $1 / 400->1 / 100$ & $1 / 9600->1 / 1200$ \\
& MFD & $1 / 200->1 / 100$ & $1 / 2400->1 / 150$ \\
\hline
\end{tabular}

S.T. $=$ Susceptibilty testing range of activity of antifungal agents at different dilution; MID = minimum inhibitory dilution; MFD $=$ minimum fungicidal dilution.

inhibited at the concentration of $125 \mu \mathrm{g} / \mathrm{ml}$. For $22(68.8 \%)$ strains of T. mentagrophytes, the inhibition occurred at concentrations up to $250 \mu \mathrm{g} / \mathrm{ml}$ of this antiseptic, and for only one strain it was at the concentration $>2000 \mu \mathrm{g} / \mathrm{ml}$. Two of the E. floccosum strains were inhibited by $125 \mu \mathrm{g} / \mathrm{ml}$, and the two others, were inhibited at $250 \mu \mathrm{g} / \mathrm{ml}$. The MFCs of própolis, for these three species, ranged from $1000 \mu \mathrm{g} / \mathrm{ml}$ to $>2000 \mu \mathrm{g} / \mathrm{ml}$ (Table 2).

\section{Fungol ${ }^{\circledR}$}

Most strains studied were susceptible to this product diluted at 1:100. The exceptions were one strain of T. rubrum (4.6\%), two strains of T. mentagrophytes $(5.9 \%)$ and one strain of $E$. floccosum. At this dilution, Fungol ${ }^{\circledR}$ presented only fungistactic activity against the other strains $(5 ; 14.7 \%)$ of $T$. mentagrophytes (Table 3).

\section{Andriodermol ${ }^{\circledR}$}

All strains were inhibited by this product at concentrations as low as 1:1200. Except for one isolate of T. mentagrophytes, Andriodermol ${ }^{\circledR}$ was lethal to all strains studied at the dilution of 1:150 (Table 3).

\section{DISCUSSION}

In general, the clinical dermatophyte isolates were susceptible to the tested antifungal and antiseptic agents in concentrations that were lower than those incountered in commercial products for topical use.

The MICs and MFCs obtained for the antifungal agents were slightly lower than those obtained for the antiseptic drugs. Terbinafine and tolciclate were the most potentially active antifungal drugs, at low concentrations against the dermatophytes studied. However, it should be noted that terbinafine at concentrations of up to $4 \mu \mathrm{g} / \mathrm{ml}$ was not lethal to $2(9.1 \%)$ of the $T$. rubrum strains and to $6(18.2 \%)$ of the T. mentagrophytes strains. The same inactivity pattern was observed for tolciclate at concentrations of up to $16 \mu \mathrm{g} / \mathrm{ml}$ against one of the 22 T. rubrum strains. Although both drugs presented the same mechanism of action $(9,10,13)$, from the data that was obtained, it can be concluded that there was not cross reactions between them. In the literature, reports were found describing the use of terbinafine, that focused the inhibitory activity of this drug. Except the work of the Arzeni et al. (1), who showed MIC up to 2,0 $\mu \mathrm{g} / \mathrm{ml}$, the MICs reported in the literature ranged from $0.001 \mu \mathrm{g} / \mathrm{ml}$ to $0.1 \mu \mathrm{g} / \mathrm{ml}(5,12,22-23)$ which were compatible with the results obtained in this work. However, the data obtained for the MFCs, with values reaching > $4 \mu \mathrm{g} / \mathrm{ml}$, diverged from the data presented by Fukuda et al. (7) and Arzeni et al. (1) to who reported values reaching up to $2.5 \mu \mathrm{g} / \mathrm{ml}$ and $2.0 \mu \mathrm{g} / \mathrm{ml}$, respectively.

The results obtained with tolciclate are in accordance to the results of Zaror et al. (24). Those authors reported that all of the dermatophytes studied by them were inhibited by tolciclate at concentrations equal to or lower than $2.56 \mu \mathrm{g} / \mathrm{ml}$. No reports were found in the literature regarding the fungicidal activity of this antifungal agent.

The drugs showing the highest MICs and MFCs were própolis and boric acid (Table 2). Unlike the própolis, boric acid was not lethal to most strains at the concentrations tested. Although the literature lacked in vitro studies regarding the effect of boric acid against dermatophytes, the papers published with própolis solely included the determination of the fungistactic action of this antiseptic. In general, data presented in those studies are in accordance with the data obtained in the work reported here. Some authors observed that the própolis ethanol extract at 10\% (15) or própolis at 5\% in hydroalcoholic gel or in propileneglicol gel (16) were able to inhibit the growth of all strains of the dermatophytes studied. In addition, comparing the activity of própolis to some specific antifungal agents, some authors (16) found that there is a similarity among the different drugs at the same concentrations that are commercially available.

Although further studies are needed, including in vivo investigations, the data obtained indicate that antiseptic drugs can be used as good alternatives in the topical treatment of minor cases of tinea pedis, leaving the specific antifungal drugs for use in the treatment of more severe cases of this mycosis. 


\section{RESUMO}

\section{Atividade in vitro de antifúngicos e anti-sépticos frente a dermatófitos isolados de pacientes com tinea pedis}

A atividade in vitro de antifúngicos e anti-sépticos foram avaliadas frente a dermatófitos isolados de pacientes com tinea pedis. Os antifúngicos estudados foram: ciclopirox olamine, cetoconazol, tolciclato e terbinafina, e os anti-sépticos foram: iodo povidine (PVPI), própolis, Fungol ${ }^{\circ}$, Andriodermol ${ }^{\circledR}$ e ácido bórico. A concentração inibitória mínima (CIM) ou a diluição inibitória mínima (DIM) foi determinada pelo método de diluição em ágar utilizando "yeast nitrogen" base modificado, e a concentração fungicida mínima (CFM) ou diluição fungicida mínima (DFM) foi determinada por subcultura em Saboraud dextrose ágar. Todas as drogas estudadas foram ativas frente aos dermatófitos em concentrações menores do que as utilizadas em produtos e/ou preparações farmacêuticas para uso tópico. Alguns antifúngicos, principalmente a terbinafina e o tolciclato, foram mais eficazes do que outras drogas estudadas, apresentando CIMs e CFMs mais baixos. Concluíu-se que os anti-sépticos representam uma ótima alternativa para tratamento tópico de vários casos de tinea pedis sendo, entretanto, os antifúngicos reservados para formas severas de tinea.

Palavras-chave: dermatófitos, antifúngicos, anti-sépticos, teste de susceptibilidade, tinea pedis

\section{REFERENCES}

1. Arzeni, D.; Barchiesi, F.; Compagnucci, P.; Cellini, A.; Simonetti, O.; Offidani, A.M.; Scalise, G. In vitro activity of terbinafine against clinical isolates of dermatophytes Med. Mycol., 36:235237, 1998.

2. Azevedo, R.V.; Komesu, M.C.; Candido, R.C.; Salvetti, C.; Rezende, F.H.C. Candida $\mathrm{sp}$ in the oral cavity with and without lesions: maximal inhibitory dilution of própolis and PERIOGARD. Rev. Microbiol., 30:335-341,1999.

3. Bodey, G.P. Azole Antifungal agents. Clin. Infect. Dis., 14:S161-S169, 1992.

4. Carazo, J.L.S.; Losada, L.O.; Sanjuan, V.P. Tratamiento actual de las micosis superficiales. Rev. Iberoam. Micol., 16: S26-S30, 1999.

5. Clayton, Y.M. In vitro activity of terbinafine. Clin. Exp. Dermatol., 14:101-103, 1989.
6. Cury, A.E. Atividade in vitro de alguns antissépticos bucais sobre Candida. Rev. Microbiol., 17:137-142, 1986.

7. Fukuda, T.; Naka, W.; Tajima, S.; Nishikawa, T. Neutral red assay in minimum fungicidal concentrations of antifungal agents. J. Med. Vet. Mycol., 34:353-356, 1996

8. Furtado, M.S.S.; Minami, P.S. In vitro susceptibility tests of dermatophytes to griseofulvin and imidazole derivates, Rev. Microbiol., 28:110-115, 1997.

9. Gupta, A.K.; Sauder, D.N.; Shear, N.H. Antifungal agents: An overview. Part I. J. Acad. American. Dermatol., 30:677-698, 1994.

10. Gupta, A.K.; Sauder, D.N.; Shear, N.H. Antifungal agents: An overview Part II. J. Acad. American. Dermatol., 30:911-933, 1994.

11. Hammer, K.A.; Carson, C.F.; Riley, T.V. Melaleuca alternifolia (tea tree) oil inhibits germ tube formation by Candida albicans. Med. Mycol., 38: 355-362, 2000.

12. Jessup, C.J.; Ryder, N.S., Ghannoum, M.A. An evaluation of in vitro activity of terbinafine. Med. Mycol., 38:155-159, 2000

13. Lacaz, C.S.; Porto, E.; Martins, J.E.C. Micologia Médica: fungos, actinomicetos e algas de interesse médico. $8^{\mathrm{a}}$ ed. Sarvier, São Paulo, 1991, 695p.

14. Lima, E.O. Estudo das Dermatofitoses em João Pessoa - Paraíba e da Atividade antifúngica de plantas medicinais da região contra alguns dos agentes isolados. São Paulo, 1996. (Ph.D. Thesis. Facudade de Ciências Farmacêuticas. USP).

15. Milena, L.; Leifertova, I; Baloun, I. Fungistatic effect of própolis. Folia Pharm. Univ. Carol., 13:29-44,1989.

16. Millet-Clerc, J.; Miclhel, D.; Simeray, J.; Chaumont, J.P. Étude préliminaire des propriétes fongistatiques de la própolis comparées à celles de queques produits commerciaux. Plant. Med. Phytother, 21:37, 1987.

17. Murray, P.R.; Drew, W.L.; Kobayashi, J.S.; Thompson, J.H. Manual of Clinical Microbiology. ASM, Washington, 1992.

18. Roberts, D.T.; Cox, N.H.; Gentles, J.C.; Babu, K.K.R. Comparison of ketoconazole and griseiolfulvin in the treatment of tinea pedis. $J$. Med. Vet. Mycol., 25:347-350, 1987.

19. Shadomy, S.; Pfaller, M.A. Laboratory studies with antifungal agents: susceptibility tests quantitation in body fluids and biossays. In: Manual of Clinical Microbiology. $5^{\mathrm{a}}$ ed. Ed. A.Balows, W.J.; Hausler Jr., K.L.; Herrmann, H.D.; Isenberg, H.J.; Shadomy. Washington, American Society for Microbiolgy, 1991, p.1173-83.

20. Soares, M.M.S.R.; Cury, A.E. Atividade de alguns antimicóticos contra fungos isolados de diferentes classes de pacientes. Rev. Bras. AN. Clin., 27: 3-11, 1995

21. Soares, M.M.S.R.; Cury, A.E.; Schreiber, A.Z. Micose superficial da região podal em indivíduos considerados imunocomprometidos. An. Bras. Dermatol., 70:211-217, 1995.

22. Schuster, I.; Schaude, M.; Schatz, F.; Mieth, H. Preclinical characteristics of allylamines. In: Berg, D.; Plempel, M. (eds.) Sterol Biosynthesis Inhibitors: Pharmaceutical and Agrochemical Aspects. Chichester. Ellis Horwood, 1988 : 449-470.

23. Venugopal, P.V.; Venugopal, T.V. Disk diffusion susceptibility testing of dermatophytes with allylamines. Int. J. Dermatol., 33:730-732, 1994.

24. Zaror, L.; Otth, L.; Mutizabbal. I. Susceptibilidad in vitro de dermatofitos, Candida y otros hongos frente a Tolciclato: estudio comparativo de dos inóculos. Rev. Argent. Micol., 9:18-22, 1986. 